out as being particularly useful for the student. First, there is a quite exceptional lack of jargon, and secondly, there are a large number of text figures drawn by Tischler in order to summarize the data of other authors' papers; these are mostly clear and easily understood.

To readers in Great Britain, Tischler's book should be of immense value as an introduction to Continental work on animal ecology, especially as practised by the German-speaking countries. It is also of great interest as a balanced appraisal of British and American work and the way it fits into a broader background as seen by one who is particularly concerned with the practical approach prevalent in present-day Germany.

AMYan Macfadyen

\section{A MYSTIC FROM FRANCE}

The Notebooks of Simone Weil

By Simone Weil. (Translated from the French by Arthur Wills.) Vol. 1 : Pp. iv +332. Vol. 2: Pp. iv +333-648. (London : Routledge and Kegan Paul, L.td., 1956.) 56s. net the set.

YONFRONTED by a couple of well-produced 1 volumes containing the disjointed thoughts of an obviously first-class brain, a reader might well expect some editorial comment, or at least some kind of introductory note. But there is nothing of the sort. Without a word of preparation, the text opens, the author beginning with a few lines of intense concern for human suffering, followed by a reference to the eternal problem of values, the nature of beauty and of art; and so on over almost the whole domain of knowledge. It may perhaps be said that this method of presentation has the advantage that no outside hand has been at work to deflect the gifted writer's aim, but one may not unfairly ask what her aim is.

In the usual sense of the word, there is probably no such thing for Simone Weil. Having already written several books (notably "The Need for Roots" and "Gravity and Grace"), these note-books were intended to form, so to speak, the water at the bottom of a deep well from which could be hauled up the (fluid) material for any number of future speculative ventures, including maybe a volume on folk-lore which might have emerged as something not ashamed to take its place within sight of "The Golden Bough". The relentless search for absolute truth is reminiscent of Pascal and of Husserl : both these savants, however, had a plan, even in their fragments, but here there is no plan. Yet again, one is reminded of Edith Stein, a pupil of Husserl's. Another glance at Simone Weil's outlook and the likeness vanishes, except for their common courage and self-abnegation. It is the difference between repose and rebellion, between peace and the sword.

Judged by her writings, it seems that Simone Weil was constitutionally incapable of coming to terms with any agency upon this earth, civil or ecelesiastical; and by these exacting standards, her meditations and by these exacting stan when considering the teaching of the Spanish Mystics (a fairly close parallel with Edith Stein's "Kreuzwissenschaft"), she adopts a fundamentally reactionary attitude, at once serious and defiant.

Metaphysical as much of all this may be, there are some surprisingly down-to-earth entries, reinforced by flashes of French logic. Thus, time and again we find the theme of physical work-in the sense used in thermodynamics-coming to the fore, coupled rather naively to the urge towards manual labour on one hand and (more carefully) to such concepts as order-disorder and entropy on the other. It can scarcely be an accident that these almost axiomatic elements in the theory of heat are found more frequently than others in the writings of the philosophers. Simone Weil wanted to collect all the experimental data extant about work and heat, but like the Greeks of old, she always fell back upon the majesty of abstract science.

In fact, in her own semi-mystical way, she puts a fine point upon the age-long argument concerning the contrast between the complete detachment of Hellas (and perhaps of almost every true philhellene) and the Renaissance, with its discovery that not only does man want to 'master' Nature, but that he can indeed do so, to a very large extent indeed. With this will to conquer came, it seems, the separation between science and art. The insatiable curiosity of the Greeks, and the materialism of the Romans, are noted as but mere examples in the unfolding of history. Between pure and applied science there is indeed a great gulf fixed.

Typical of this outlook is a note on p. 157. "Find somebody who can tell me whether the second principle of thermodynamics is regarded as valid in biology ?" Conceivably, if Simone Weil's voracious appetite for reading had included Prof. Bertalanffy's "System Theory", she might have found the answer. This ingenious calculus provides, as is commonly known, for 'open' systems; whether it will stand the test of time remains to be seen. It depends upon a degree of balance unlikely to be attained in many categories of mechanical assemblages. But the point is significant; she recoils from the idea of total degradation of energy. Within limits, she may be right, and there the quantum theory supports her.

Psychologically, it would be an almost impossible task to place Simone Weil. In broad outline, she must have been a strong introvert. Her passion for serving others, however (for example, her work for the resistance movement of her native land), dèsignates her an extrovert indeed. But the link which united the two, in unstable equilibrium, was a kind of Aristotelian potency, straining at the leash to pass into entelechy at the slightest provocation. Her whole life appears as a sublime human example of the physicist's critical state; the phenomenon of flickering striæ associated with a condition in which pressure and volume are increasing simultaneously.

It will be noticed that this review refers to the composer of these note-books in the past tense. All too little known, and still less revered in her lifetime, Simone Weil was born in 1909. At one time she taught in a French secondary school, and at another period voluntarily engaged in strenuous manual labour. She was in England during the Second World War, died at Ashford (Kent) in August 1943, and was buried in a common grave, No. 4779 . Quite recently, a movement has been set on foot to erect some simple memorial of her.

These nascent jottings give the impreasion of an intense striving for intellectual and spiritual per. fection on the way to further creative effort. But they represent all too clearly what in the event proved to be the last will and testament of a tortured mind.
F. I. G. Rawlins 